The Geneva Papers on Risk and Insurance, 21 (No. 78, January 1996) 77-107

\title{
The European Internal Insurance Market: Expectations, Assessments and Consequences for Business Policy from the Insurers' Point of View Questionnaire Results
}

\author{
by Gerd Weidenfeld*
}

\section{Introduction}

The Third Generation of EC Insurance Directives has already been incorporated into many member states' legal systems. Apart from a few countries that have been granted extended transitional periods by the EU, the remaining member states are on the brink of implementation. In addition, several states from the rest of the EEA ${ }^{1}$ have announced their intention to implement the Directives. Thus the legal framework has largely been created for the establishment of the EC internal insurance market.

With this in mind, the Institute of Insurance Studies at Cologne University carried out a study in conjunction with the Geneva Association to investigate:

1. The insurers' subjective expectations for the EC internal market and

2. What business policy conclusions the European insurance undertakings will draw from these changes to the business environment.

This study was important as to date all that has been available are - more or less plausible - hypotheses about insurance undertakings' behaviour in the future EC internal insurance market. Attempts to validate these assumptions empirically predate the adoption of the Third Directives and are therefore only of limited use for current investigations. ${ }^{2}$

* University of Cologne, Germany.

1 Although Switzerland has not joined the EEA Agreement, for the sake of simplicity it is regarded as an EEA member in the context of this investigation.

2 A similar survey was carried out by Farny in 1988/89, the results of which are recorded in Farny, Dieter: Erwartungen europäischer Versicherer an den Binnenmarkt [European Insurers' Expectations for the Internal Market], in: ZVers. Wiss., Vol. 78, 1989, pp. 67-106. A Delphi Study of the same subject was carried out by Andersen Consulting. See: Andersen Consulting (Ed.): Insurance in a Changing Europe, Special Report No. 2068, London 1990. A summary in German of the results of this study and a presentation of German and Swiss survey results was published in: Andersen Consulting (Publisher): Zur Entwicklung des europäischen Versicherungsmarktes [The Development of the European Insurance Market] 1990-1995, Stuttgart 1991. 


\section{Basis of the investigation}

In this study we approached the management of 400 insurance undertakings from all EU member states, Switzerland and Norway. This corresponds to about $10 \%$ of all insurers operating there. They were asked to give their assessments, predictions and business policy conclusions for the next ten years. The respondents were guaranteed completely anonymity when the results were evaluated and published.

To this end, the Institute of Insurance Studies at Cologne University drew up a questionnaire that was sent out in German, English and French. The number of insurers per country that the questionnaire was sent out to was determined by each country's share of the total premium volume in the EEA. As predictions and business policy conclusions can depend on an undertaking's size, care was taken when selecting the survey sample to ensure an equal distribution of small, medium sized and large insurers. The small and medium sized insurers were chosen on a random basis. As far as the large insurers were concerned, the companies written to were mainly those managed by members of the Geneva Association. This way of selecting a sample can be regarded as representative of the European insurance market.

110 useable completed questionnaires were returned. The return quota of $27.5 \%$ that was thus achieved correponds approximately to the usual average for investigations of this nature. The distribution of answers from individual countries is shown in the table below:

\begin{tabular}{|l|r|r|}
\hline \multirow{2}{*}{} & \multicolumn{2}{|c|}{$\begin{array}{c}\text { Country of Origin } \\
\text { of the Responding Insurers }\end{array}$} \\
\cline { 2 - 3 } & Count & $\%$ \\
\hline Belgium & 1 & $0,9 \%$ \\
Denmark & 1 & $0,9 \%$ \\
Germany & 49 & $44,5 \%$ \\
France & 9 & $8,2 \%$ \\
Greece & 1 & $0,9 \%$ \\
Great Britain & 16 & $14,5 \%$ \\
Eire & 1 & $0,9 \%$ \\
Italy & 5 & $4,5 \%$ \\
Netherlands & 3 & $2,7 \%$ \\
Portugal & 1 & $0,9 \%$ \\
Spain & 5 & $4,5 \%$ \\
Finland & 2 & $1,8 \%$ \\
Austria & 6 & $5,5 \%$ \\
Sweden & 2 & $1,8 \%$ \\
Switzerland & 8 & $7,3 \%$ \\
\hline
\end{tabular}

The fact that the Institute is very well known in Germany accounts for the fact that the proportion of answers from that country is too high in relation to its share of total premium volume in the EEA. Generally speaking, only a small number of replies were received from 


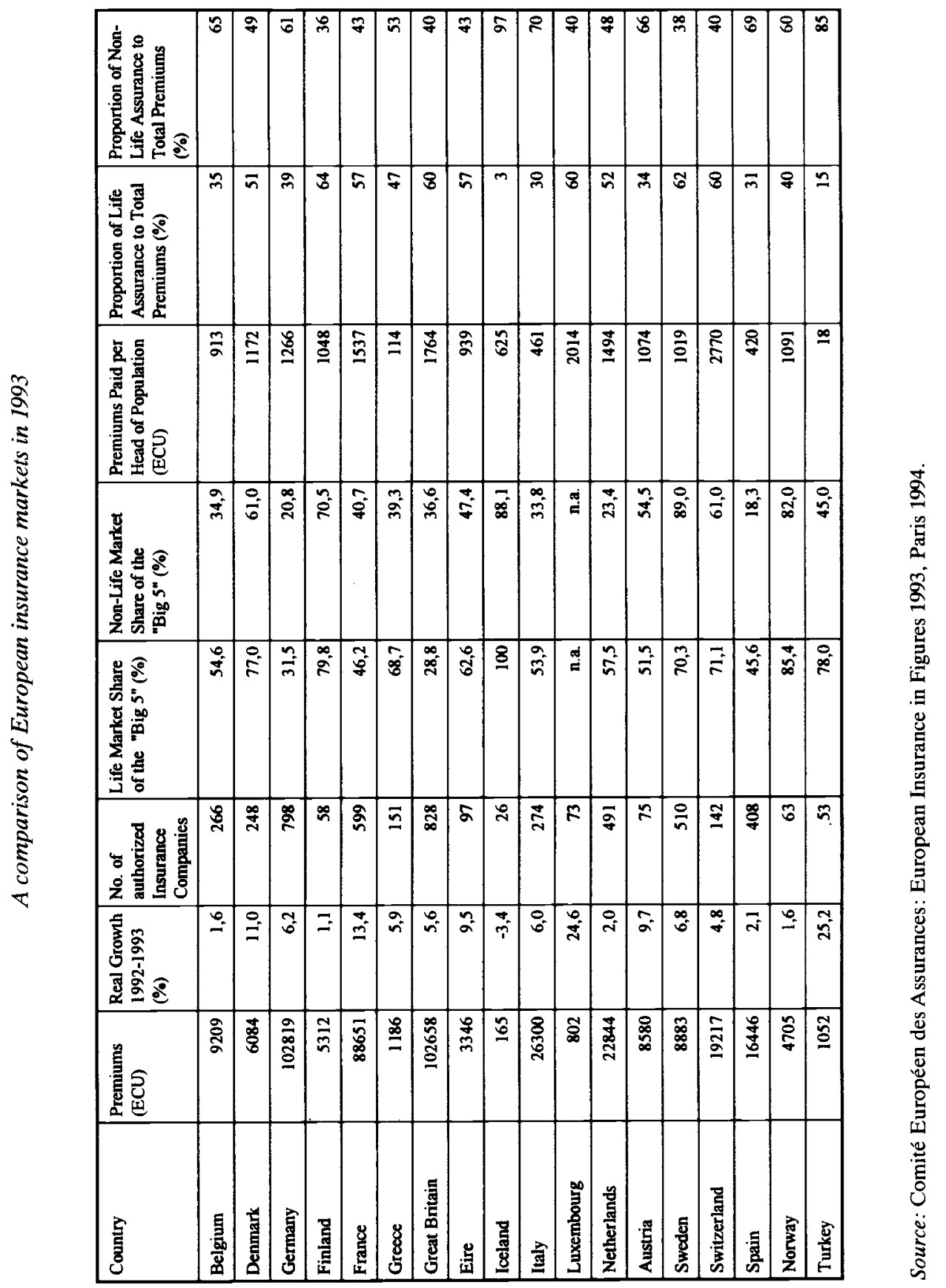


insurers who were not written to in their own language. Any distortions of the results that may be due to this inequality of distribution have been taken into account when interpreting the data.

\section{A comparison of European insurance markets}

The table on the previous page reproduces some of the important characteristics of the European insurance markets.

\section{Expectations and assessments according to the respective countries of origin of the responding insurers}

\subsection{Supervision}

The insurers taking part in the investigation were asked about the effect of the implementation of the Third Generation Directives on the degree of supervision in their respective countries of origin. $61.2 \%$ of the respondents thought it would lead to a decrease in state supervision, $18.4 \%$ anticipated that the new degree of supervision would be higher than previously and $20.4 \%$ foresaw no change in the degree of supervision. An increased or unchanged degree of supervision in their own countries was above all anticipated by British, Irish and Dutch insurance undertakings. This is not surprising, as these markets were already regarded as liberal before the adoption of the Third Directives, so that there was comparatively little potential for deregulation. By contrast, the effects of deregulation were principally noted by insurers from Germany, Austria, Italy and Switzerland, i.e. markets where there is a tradition of strong supervisory authorities with wide ranging powers.

When asked about the extent of the existing degree of supervision in comparison to that of other countries, $56 \%$ regarded their degree of supervision as being relatively high. This was influenced by the high proportion of answers from German insurers, of whom nearly $80 \%$ regarded their degree of supervision as being relatively high. Only $6 \%$ of all those surveyed see their home market as less supervised than the EEA average. Thus if "supervisory oases" still really do exist in the internal insurance market, they are not perceived as such by the insurers based there.

The table below shows the distribution of answers to the question about the influence of the degree of supervision on competition with insurers from other EEA states.

A relatively high degree of supervision is apparently perceived as a disadvantage by those affected by it. This opinion was expressed by about $55 \%$ of those insurers who felt that they were relatively strongly regulated. On the other hand although a relatively low degree of supervision is not seen as a disadvantage, it is also not seen as a definite advantage either, as evidenced by the equal number of answers indicating "more of an advantage" and "neither an advantage nor a disadvantage".

According to the concept underlying the EU internal market, the different supervisory systems should compete with each other in the hope that this will allow the particular degree of supervision achieving the best market results to establish itself throughout Europe. Only about half of the insurers asked accepted the validity of this "alignment 


\begin{tabular}{|l|c|c|c|c|}
\hline & \multicolumn{2}{|c|}{ ASSESSMENTOF SUPERVISION } & \\
\cline { 2 - 5 } $\begin{array}{c}\text { Row Pct } \\
\text { Tol Pct } \\
\text { Tot Pct }\end{array}$ & Favourable & Unfavourable & Neither/nor & \multirow{2}{*}{ RowTotal } \\
\hline PERCEIVED DEGREE & & & & \\
OF SUPERVISION & & & & \\
relatively high & 14,3 & 55,4 & 30,4 & 56,0 \\
& 38,1 & 88,6 & 38,6 & \\
relatively low & 8,0 & 31,0 & 17,0 & \\
\cline { 2 - 5 } & 50,0 & & 50,0 & 6,0 \\
average & 14,3 & & 6,8 & \\
& 3,0 & & 3,0 & \\
\cline { 2 - 6 } Column total & 26,3 & 10,5 & 63,2 & 38,0 \\
\cline { 2 - 6 } & 47,6 & 11,4 & 54,5 & \\
\cline { 2 - 6 } & 10,0 & 4,0 & 24,0 & 100,0 \\
\hline
\end{tabular}

theory". However, the frequently feared alignment at the lowest European degree of supervision $^{3}$ is just as seldom expected as an alignment at a high degree of supervision - "balancing out" at an average level is seen as much more probable.

One consequence for business policy arising from competitive disadvantages related to supervision could be the relocation of company headquarters to countries with a more favourable supervisory environment. However, only about $18 \%$ of respondents anticipate a scenario of this nature. The fact that three quarters of those insurers who feel they are strongly supervised do not expect to relocate their company headquarters permits the conclusion that the expected disadvantages of a high degree of supervision when competing with insurers from other EEA countries are not perceived as very serious.

\subsection{Demand}

\subsubsection{Anticipated growth}

The table below shows how strong the insurers estimate average growth (net of inflation) to be in their home markets over the next ten years. Such estimates are usually problematic, as apart from nominal expected growth, the inflation rate has to be predicted as well. The latter is subject to considerable uncertainties, particularly in countries with high and markedly fluctuating inflation rates.

${ }^{3}$ See: Loheac, Francis: Der Binnenmarkt für Versicherungen: Chancen, Grenzen und Perspektiven [The Internal Insurance Market: Opportunities, Limits and Perspectives], in: Versicherungswirtschaft, 49th year, 1994, p. 1120. 


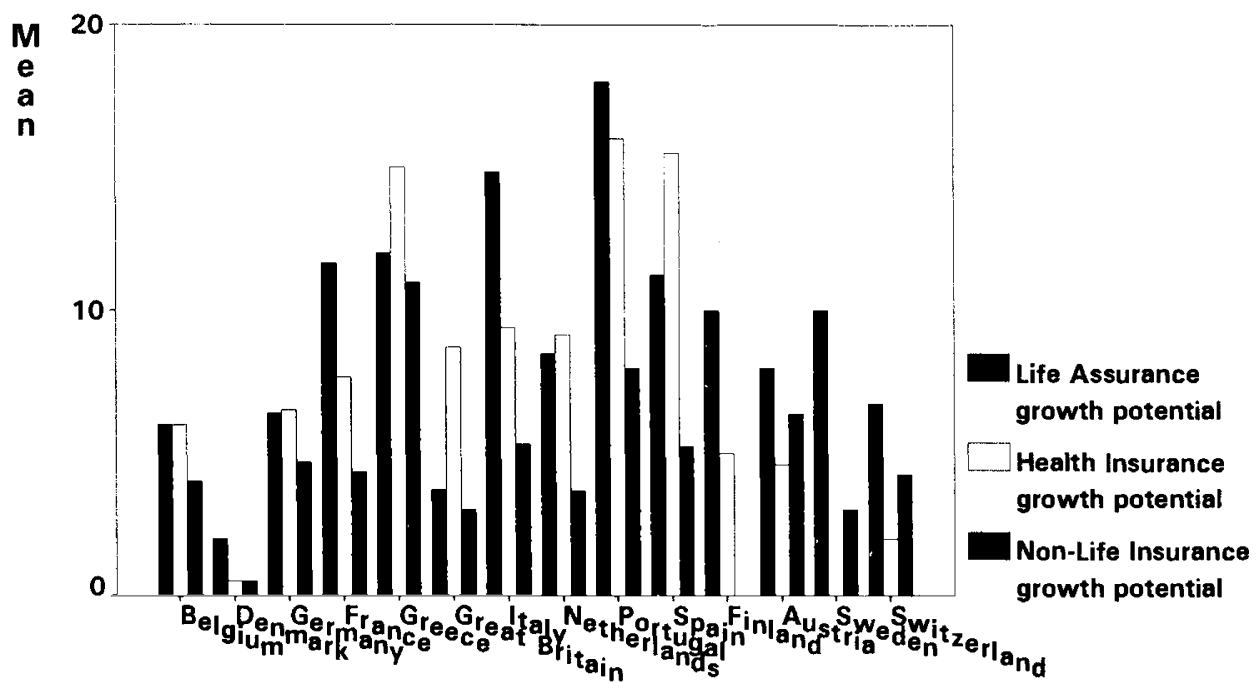

Country of Origin of the responding Insurance Undertakings

It is apparent, however, that overall the prospects for real growth are certainly seen in an optimistic light. Higher growth rates are expected in countries where insurance has so far only had a limited impact (Greece, Spain, Portugal, Italy) than in the more saturated markets. In all markets except for Austria and Switzerland, the growth potential of personal insurances is thought greater than that of property insurance. This high expectation for increasing demand in the areas of private health insurance, pensions and life assurance can be explained by the declining performance of social security systems financed on an assessmentism basis which face considerable problems due to the unfavourable demographic development in all West European countries.

\subsubsection{Anticipated changes in consumer behaviour}

Whether the benefits of the internal insurance market expected by the EU Commission actually come about, principally depends on whether customers change their existing behaviour in respect of purchasing insurance and make use of the new possibilities created by the internal market.

An insured's willingness to purchase cover from a foreign insurer determines the success of freedom of establishment (that has existed since 1973 for non-life insurance and 1979 for life assurance) and of freedom of services (that has existed since 1990 for large risks and 1994 for mass risks). The readiness of private customers and small businesses to buy cover at the present time from a foreign insurer established in their country was estimated overall at a median value of approximately 4.5 on a scale of 1 (Not Willing) to 10 (Very Willing). This willingness is expected to rise to 6 over the next ten years. The expectations are even more optimistic for large commercial customers: with a current value of 6 , and an anticipated value of 7.5 in ten years time, the prospects for success of freedom of establishment are here seen as better than for private insureds and small businesses. 
More relevant is the question about the insureds' expected acceptance of freedom of services. The current willingness of private customers and small businesses to buy cover from a foreign insurer without a local subsidiary company or branch is estimated at a median value of only 1.9. Although an increase in this value is expected, the respondents did not think it would rise above 3.2 in the next ten years. The prospects for success of freedom of services in relation to private customers is thus estimated as being significantly lower than for freedoim of establishment.

As far as large commercial customers are concerned, the situation is perceived differently, as freedom of services has existed here since 1990. With a current expected value of 4 , rising to 5.7 in ten years time, the respondents' view is that the fact that selling insurance cover to large commercial customers via freedom of services has so far only reached modest proportions is not due to customers' reservations.

\subsubsection{Consumer benefits}

The primary benefits of the EU internal insurance market to be expected for the consumer should be products that are more orientated to the needs of the consumer and at more reasonable prices. The lack of market transparency arising from the abolition of the requirement for approval of premium rates and policy conditions is to be overcome by the emergence of new market sources of information. The continuing existence of financial supervision should guarantee that insurance undertakings have sufficient security resources necessary for the continuing fulfilment of their obligations to the insureds.

The respondents predicted both positive and negative consequences for the insureds in their countries of origin. Three quarters of the respondents believe that private and commercial customers will in future be offered products that are more consumer orientated. It is interesting to note that the respondents from the traditionally highly regulated German market share this opinion with insurers from the liberal British market. The undertakings in France and Switzerland are somewhat more conservative in their judgement of the situation relating to private customers; here only $50 \%$ and $57 \%$ respectively anticipate products that are more consumer orientated. The danger that the EU internal insurance market will lead to products that are less consumer orientated is expected by only $12 \%$ of respondents in respect of private customers and by just $2.6 \%$ in respect of commercial insureds. Commercial customers are therefore expected to be in a much better position than private insureds when judging the extent to which insurance products meet their needs.

Approximately $75 \%$ of the insurers surveyed also predict better value for money in their countries of origin, both in respect of private and commercial insureds. This opinion is held by respondents from every country, although only $42 \%$ of the Swiss insurers were in agreement in so far as private customers are concerned - an equal number consider it more likely that private customers will receive worse value for money.

No clear conclusions can be drawn as to the development of market transparency for private customers. Although $68.7 \%$ of all insurers surveyed foresee a reduction in market transparency in their countries of origin, this figure has to be put into context as $95 \%$ of German respondents, all Austrians and $86 \%$ of the Swiss respondents were of this opinion. The high proportion of these countries in the sample distorts the result. The majority of the respondents from other markets did not share this view; instead they expected either no change or even an improvement in market transparency for private customers. The development of market transparency for commercial insureds tended to be assessed more 
optimistically. Here only about $40 \%$ of all respondents expected the situation to get worse and it is clear that commercial insureds are perceived as better equiped to obtain and assess information.

Expectations about security as to the due fulfilment of insurance contracts only differ slightly from those concerning market transparency. $57 \%$ of respondents expect decreased security for private customers in their countries of origin, $40.9 \%$ foresee this for commercial insureds as well. This difference again may be explained by the assumption that commercial customers are better equiped to obtain and assess information. As with the assessment of market transparency, the spread of answers here is also strongly dependent on the respondents' countries of origin. It is above all in the traditionally highly regulated markets that the majority of insurers foresee decreased security. However, differences of opinion were voiced in the other countries as well.

When asked for their overall evaluation of the EU internal insurance inarket from the insureds' point of view, the conclusions reached by the respondents were predominantly positive. Almost 59\% of all respondents think it is likely to result in greater advantages for private customers; only $29 \%$ foresee more disadvantages, whilst the rest consider that the internal insurance market will bring neither advantages nor disadvantages for private customers. The assessment in respect of commercial customers is even more positive, as $76.3 \%$ see greater advantages for this sector of customers and only $5.4 \%$ expect disadvantages.

In traditionally highly regulated markets, some of the national insurance supervisory authorities' powers have been significantly limited by the Third Coordination Directives. Some of these powers had the effect of providing considerable consumer protection for the mass market (e.g. the requirement for prior approval of rating structures and policy conditions). These preventative measures are primarily being replaced by subsequent supervision of misconduct and wide ranging duties of disclosure on the part of the insurers before contracts are concluded.

Consumer protection will be improved in their countries of origin according to $44 \%$ of respondents, in other words, the new consumer protection measures are considered more effective than those that existed prior to the implementation of the Third Directives. $33 \%$ think that consumer protection will be reduced, although not to a significant extent. $20 \%$ expect consumer protection to decrease significantly but to remain adequate, with only $3 \%$ anticipating insufficient protection for insureds.

About half of all those respondents who expect a reduction in the level of consumer protection responded to the question whether steps should be taken to counter this. Only $25 \%$ of the answers expressed agreement. Self-regulation by the industry (e.g. by insurance associations) and supervision of insurance intermediaries were most commonly put forward as suitable counter-measures. The establishment of a protection fund, to be used if a company goes into liquidation, was only suggested by one insurer. ${ }^{4}$

4 The appropriateness of a protection fund is a matter of some controversy. According to Farny the disadvantages of such a consumer protection instrument outweigh the advantages. See Farny, Dieter: Ein Konkurssicherungsfonds in der Versicherungswirtschaft, Ei des Kolumbus oder Windei? [A Protection Fund for the Insurance Industry, Solution or Illusion?], Karlsruhe 1990. Finsinger takes a different view. See Finsinger, Jörg: An Integrated Market in Western Europe - Selected Issues, in: Emil Ems (Editor): Financial Integration in Western Europe - Structural and Regulatory Consequences, Sveriges Riksbank, Occasional Paper 10, (Place and date not stated), p. 87; ibid: Konkurssicherungsfonds und optimale Sicherheitsregulierung [Protection Funds and Optimum Security Regulations], in: Geld, Banken und Versicherungen [Money, Banks and Insurance], Karlsruhe 1987, Volume 2, pp. 1213-1254. 


\subsection{The supply side}

The undertakings surveyed share the concern voiced in some quarters that the EU internal insurance market will bring with it an increase in the number of companies bought and sold, going into liquidation and entering into mergers, leading to concentration within the national markets and also throughout the EEA. 89\% of answers expect an increasing level of concentration in their own countries of origin and $91 \%$ also foresee this throughout the EEA. Very few anticipate any reductions in concentration that have theoretically been made possible by the Third Directives' removal of barriers to market entry.

In the EU internal insurance market, the legally non-independent branches of EU insurers are no longer supervised by the country of operation, but by the parent company's country of origin. If a company from a relatively weakly supervised market opens a branch in a highly supervised market, the lower level of supervision can be imported into the country of operation, whilst at the same time ensuring the local presence that is so important for transacting insurance. $52 \%$ of the respondents expect an increased number of branches in their countries of origin because of these new regulations. As is to be expected, this figure is somewhat higher $(56.6 \%)$ for insurers who see themselves as relatively highly supervised.

The level of competition will be permanently increased as a result of the EU internal insurance market, at least according to three quarters of the respondents. However, there are considerable differences of opinion about the causes of this increase in competition. Increasing competition can either be due to growing numbers of insurers from other EEA states (the effect of the internal market) or due to the deregulation that follows the implementation of the Third Coordination Directives (the effect of deregulation). Thus in previously highly regulated markets such as Germany, Switzerland and Italy, the effect of deregulation is seen as considerably more important than that of the internal market. On the other hand, in France and Great Britain greater importance is attached to the effects of the internal market. The Austrian insurers' opinion is remarkable in that they rated the effect of deregulation as less than the effect of the internal market, despite having previously been subject to a high degree of regulation themselves. What is equally surprising is that, in as many as $30 \%$ of the answers, the internal market and deregulation effects do not add up to $100 \%$ - thus apart from the internal insurance market, other factors leading to increased competition are also being discerned.

In connection with the effect of the internal market, the survey asked for a rating of the activities of competitors from other countries expected to operate in the respondents' countries of origin. The answers were to be on a scale of 1 (= no activity expected) to 10 (= high level of activity expected).

As the table shows, insurance undertakings from France (6.47), Germany (6.26), Great Britain (6.17) and Switzerland (5.84) are rated as particularly aggressive in this respect. At a somewhat lower level are the Netherlands (4.68) and Italy (4.30). Interest in activities in the EEA is also expected from US American and Japanese insurers (4.09 and 3.40). As far as the remaining markets are concerned, they are hardly expected to be active abroad. The answers also reveal that neighbouring countries with a common frontier feel much more threatened by each other than countries that do not directly border on each other. The internal insurance market will thus be effective not so much throughout Europe but rather between neighbouring countries. Here national differences in terms of cultural, linguistic and economic factors are less marked than between markets that are further apart, thereby making it easier to enter neighbouring countries' markets successfully. 


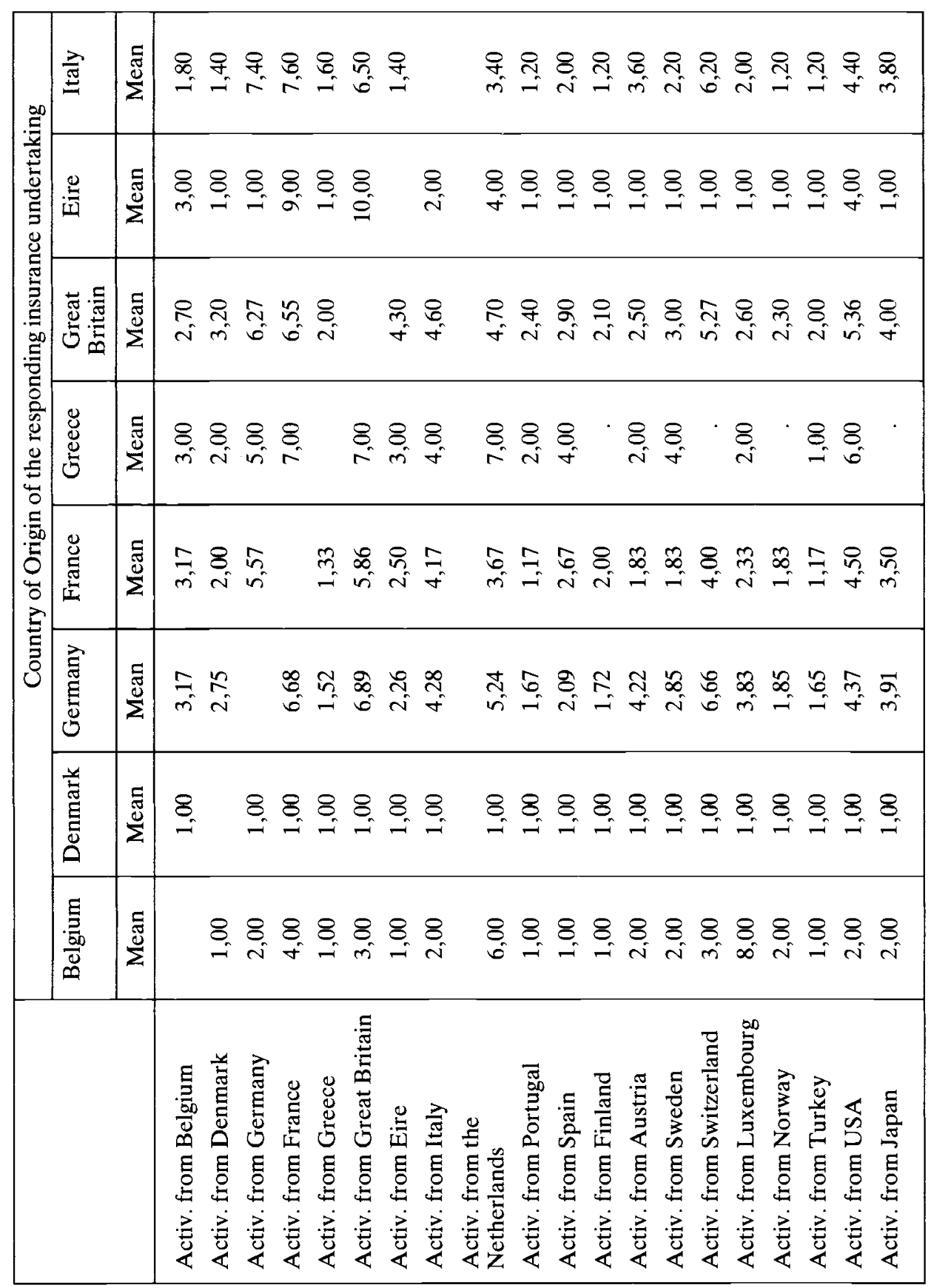




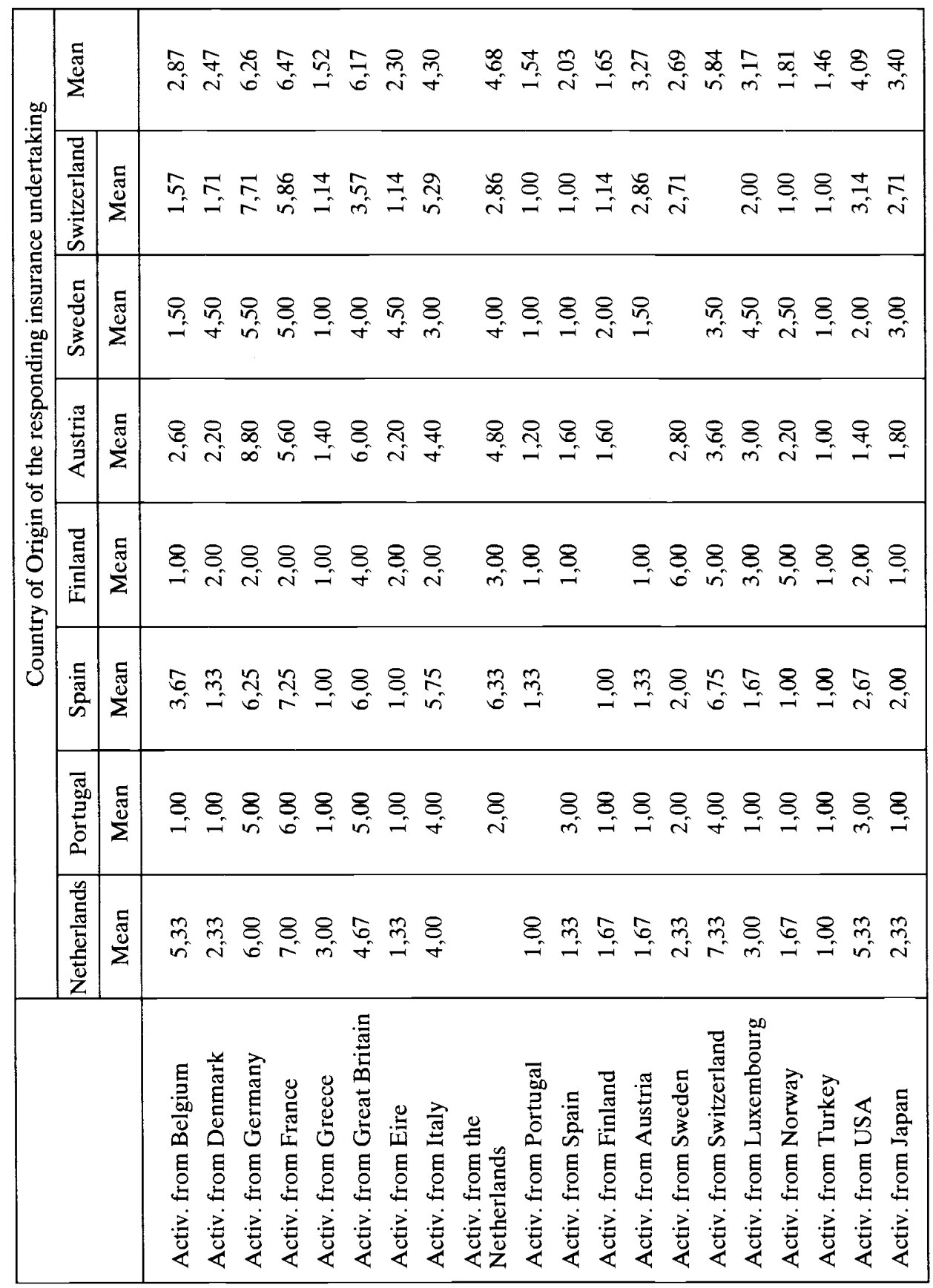


The future profitability of insurance undertakings tends to be seen in a rather pessimistic light. $56 \%$ anticipate decreasing profits in their countries of origin, $28 \%$ expect profits to remain unchanged. German, British and Austrian insurers were particularly pessimistic in their views.

One consequence of increasing competition could be individual insurers going into liquidation. Such a development would above all be conceivable in markets that have been highly regulated until now, allowing mediocre companies to survive. In the traditionally liberal markets, several such companies have already left the market in the past, so that these countries have by now been through a "purification process". This view is not confirmed by the respondents. Although $40 \%$ expect an increase in the number of liquidations in their countries of origin, it is not in fact the insurers from previously highly regulated markets but those from the relatively small insurance markets, such as Portugal, Spain, Greece and Italy, that are particularly pessimistic. In addition, nearly $70 \%$ of the British insurers expect an increase in the number of liquidations in their own country. By contrast, such a development is hardly or not at all envisaged in Germany, Austria and Switzerland.

Nearly $64 \%$ of those taking part in the investigation expect an increasing number of liquidations in the whole of the EEA. Insurers who anticipate an increase in the number of liquidations in their home markets expect the same to apply throughout Europe. Respondents who do not expect an increase in the number of liquidations in their own countries are considerably more pessimistic about insurance liquidations in the EEA as a whole.

The expected relationship between individual national insurance industries in the European internal insurance market was also investigated. In principle two extreme positions are conceivable:

1. On the one hand the individual insurance industries adopt an aggressive business policy in order to strengthen their position in other EEA markets. On the other hand they use all methods possible in the attempt to prevent foreign competitors from successfully entering their home market. ("War scenario").

2. Insurers develop the European internal insurance market by means of international cooperation and partnerships. ("Peace scenario").

Only $14.5 \%$ of all respondents anticipate the "war scenario" in the short term, $13.6 \%$ in the long term. The "peace scenario" is seen as much more likely, as in the short term this is expected by $46.6 \%$ of all respondents and by $57.3 \%$ in the long term.

$26.4 \%$ do not foresee either of these scenarios relating to international competition as likely in the short term, nor do $16.4 \%$ in the long term. Those operating in the insurance sector do not therefore expect there to be the ruinous competition in Europe in order to drive rivals out of the market, that can be observed in other parts of the economy (e.g. steel manufacturing).

\subsection{Intermediaries}

The questionnaire investigated whether the theory variously put forward that the liberalisation of insurance markets will lead to a significant reduction in the market share of "tied distributors" (employed sales force, sole agents and banks) also agrees with insurers' 
expectations. ${ }^{5}$ This theory is based on the assumption that the insured's need for "objective" advice increases as the level of product standardisation decreases. As tied distributors can only offer the products of one insurance undertaking, the advice they give can only refer to in-house products. In contrast to this, brokers and multi-company agencies can offer products from different insurers, which should increase the quality of the advice given. This assumption is supported by the empirical observation that tied distributors have a high market share in strongly regulated markets and that independent distributors have a high market share in liberal markets. ${ }^{6}$

The survey participants were asked to predict the changes in each distribution system's share of total national premium income for their country of origin. In all markets (except Spain) the companies' own distribution networks (e.g. employed sales forces and branches) were identified as likely to lose market share. The future of tied distributors (e.g. sole agents) was seen in a similar light. This confirms the assumptions stated above.

It is above all in the previously highly regulated markets such as Germany, Italy, Austria and Switzerland that brokers and multi-company agencies are expected to increase their market shares. This result also corresponds to the original assumption; however, it is not confirmed by the development of banks as a distribution system. This distribution channel is expected to increase its market share significantly in every market, sometimes by over 10 per cent. It is noteworthy that this prediction was made both by previously highly regulated markets and by the liberal ones as well.

The future of distribution via partners (not banks) in a cooperation agreement, for example car dealers acting as motor insurance agents, was rated in a uniform manner. No major changes in market share are expected here. Although this distribution system will no doubt continue to hold its ground in the future, the limits to its potential do seem to have been reached.

All survey participants think that "direct selling", i.e. selling insurance over the telephone or by mail, will also win increased market shares. As no commissions have to be paid to intermediaries in this type of distribution system, it has already achieved notable success with customers who are price conscious and require little advice, above all in the areas of life and motor business. The numerous "direct" subsidiaries that have recently been founded by insurance undertakings that had hitherto only used classic distribution systems bear witness to this distribution channel's anticipated success.

\section{Consequences for business policy}

\subsection{Collective strategies $v$. individual strategies}

In most of the EEA states, the deregulation connected with the implementation of the Third Directives will open up new commercial freedoms for insurance undertakings. The more strongly an industry was regulated previously, the greater these new freedoms will be.

\footnotetext{
${ }^{5}$ See Finsinger, Jörg, Schmid, Frank A.: Gebundener versus ungebundener Vertrieb. Theorie und empirische Evidenz für europäische Versicherungsmärkte [Tied versus Independent Distributors. Theory and Empirical Evidence for European Insurance Markets], in: Zeitschrift für Betriebswirtschaftliche Forschung, 45th year, 1993, p.225.

6 Ibid, pp. 222-226.
} 
These new opportunities (the extent of which will vary from country to country) can be used by insurance undertakings in different ways. The following basic approaches are possible:?

A. Every company will make use of these new freedoms in its own individual way, with the result that, where there were previously more regulated (and therefore more unified) market situations, there will now be many different aspects to the market situation. ("Chaos scenario").

B. The insurance undertakings will try to preserve the unified nature of the previously regulated market situation and coordinate the way in which the new freedoms are used (e.g. taking advantage of special provisions of the cartel laws regarding the group exemption rules). ("Convoy scenario").

The survey participants were asked to predict how the insurance industry in their respective countries of origin would act, using a scale of 1 (= no coordination) to 10 (= complete coordination). Median values of 6.4 for expected short term coordination and 5.0 for the degree of coordination in ten years time show that the survey participants for whom the Third Directives have brought deregulation anticipate a medium degree of coordination that will only lessen to a small extent over time. Although the replies vary according to the country of origin of the undertakings asked, there is little variation within each country's replies. A decrease in coordination from 6.7 to 5.0 was expected in Germany, from 5.8 to 4.3 in Italy and from 7.0 to 4.0 in Austria. In this respect the views of Swiss insurers are significantly different; in the short term they anticipate a coordination level of 4.2 , although this is expected to increase to 6 in ten years time. No country foresees a chaos scenario, either in the short or the long term, nor does any country expect complete coordination. It is much more likely that previous state regulation will be partially replaced by a type of "self regulation" of the market by the insurers. New freedoms, particularly those relating to product and pricing policy, will only be taken advantage of to a limited extent. This will in turn have a positive effect on market transparency.

\subsection{Polarisation strategies}

\subsubsection{Introductory remarks}

The "polarisation theory" was the starting point for questions about the business policy conclusions that insurers draw from the changes to the market environment. This theory predicts that in very competitive markets there will be a tendency for the participants and products therein to move away from the average positions towards the extreme positions, because their goals can be more easily reached from the latter than from the former. Over a long period of transformation and adjustment, insurers will try to set their own core business activity parameters in such a way as to distance themselves from the average and develop their own independent profile. This will result in the development of two sorts of insurer: firstly the large composite insurer, transacting business - possibly world wide - of every type with every possible customer group using all possible distribution systems,

7 See Farny, Dieter: Über mögliche Unternehmensstrategien deutscher Erstversicherer im deregulierten Versicherungsmarkt [Possible Business Strategies of German Direct Insurers in the Deregulated Insurance Market], in: Risiko. Versicherung. Markt., Festschrift für Walter Karten, Karlsruhe 1994, p. 248 et seq. 
and secondly, the small specialist working only in selected business areas, in other words, transacting only certain types of insurance with certain customer groups by means of certain distribution channels, possibly only in certain regions. 8 The better prospects of success enjoyed by such "niche operators" were confirmed by an internal study carried out by McKinsey in 1992 which investigated the profits and growth of 200 non-life insurance companies from France, Germany and Great Britain. The "focussed specialist insurers", who predominantly concentrated either on one product, a defined group of customers, one distribution channel (other than tied agencies) or a specific region, were identified as the undertakings with by far the best level of performance. ${ }^{9}$

Questions about the policies relating to product ranges, price, the products themselves and distribution should determine whether insurers really are "distancing themselves from the average" because they wish to develop their own profile, or whether they are in fact continuing to orientate their core activity parameters towards the industry average. As a group of companies can have a multi-facetted profile due to the different strategic directions of its subsidiaries, it cannot be evaluated by means of a standardised questionnaire. ${ }^{10}$ For this reason, these questions were only to be answered from a single undertaking's point of view. Aspects relating to groups were to be specifically excluded.

\subsubsection{Product range}

The insurers surveyed were asked to indicate the number of classes of business they transact today and how many they wish to transact in ten years time. Answers were expressed on a scale of 1 to $10(1=$ a single class, $3=$ few, $8=$ many, $10=$ every class of insurance). As is shown on the diagram below, the numbers most frequently given for classes of business transacted today were 3,8 and 9 ; fewer insurers regard themselves as being in the middle or at the extreme ends of the scale.

A tendency towards polarisation of classes of business would have the effect of increasing the concentration of numbers at the outer ends of the scale 1,2,3 and 8, 9, 10 and reducing the number in the middle. However, this is not in fact the case: in future the extreme ends of the scale will be less populated than at present according to the responding undertakings, and the middle positions will take on greater importance. Overall the survey participants show considerable stability in relation to the number of classes of business they transact: $76 \%$ of the answers on this scale either remain unchanged or are only moved one place to the left or right.

8 Ibid, pp. 252-256.

${ }^{9}$ See Muth, Michael: Versicherungswirtschaft im Umbruch [The Insurance Industry in a Time of Change], in: Versicherungswirtschaft, 49th year, 1994, p. 291 et seq.

10 See Farny, Dieter: Über mögliche Unternehmensstrategien deutscher Erstversicherer im deregulierten Versicherungsmarkt [Possible Business Strategies of German Direct Insurers in the Deregulated Insurance Market], as above, p. 261. 


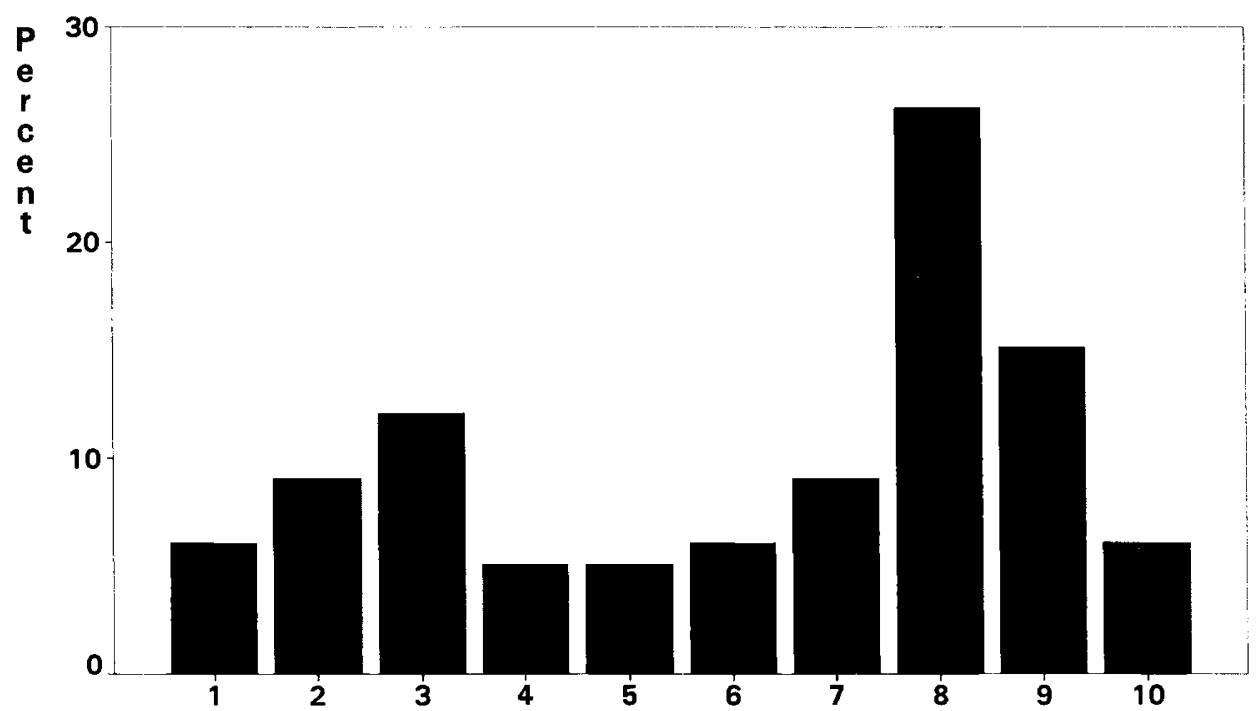

Number of classes of business transacted (today)

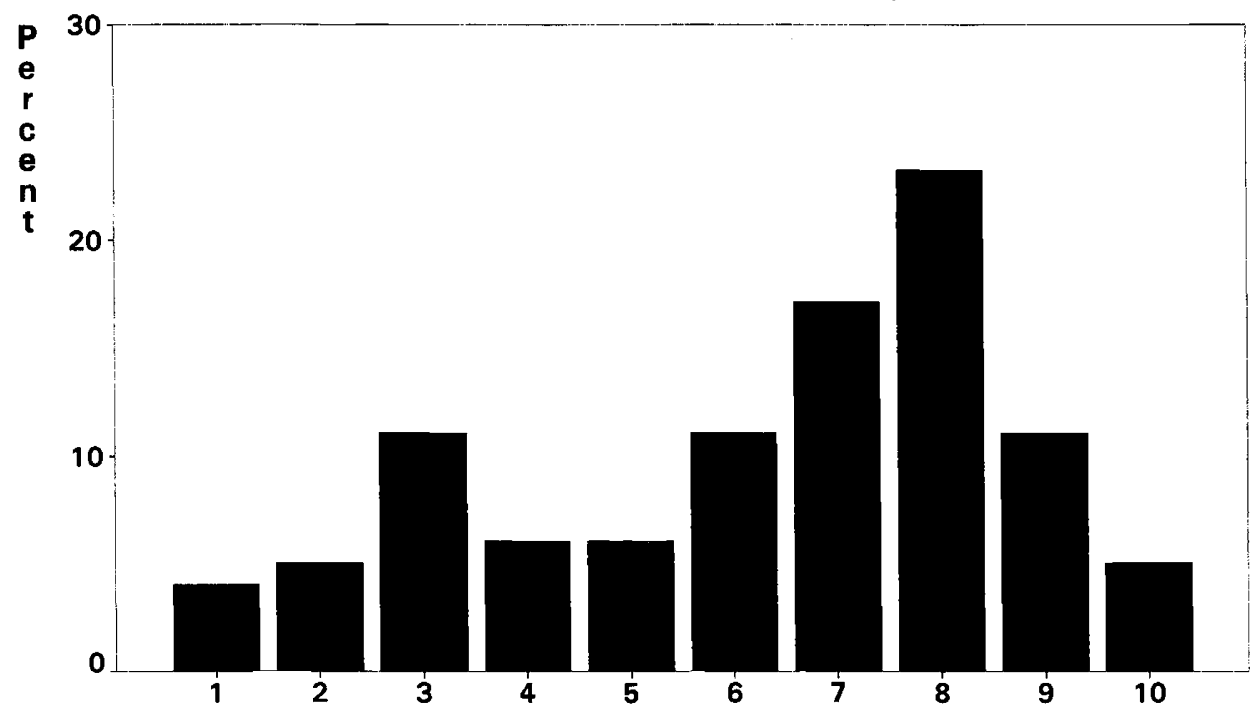

Number of classes of business transacted in 10 years time

There was also no confirmation of the suspected polarisation in the number of products offered within the different classes of business. Whereas the values 1-3 can maintain their position in the future, the current weighting on the right hand side of the scale will shift towards the mid-range values. This situation provides neither the advantages of a complete product range nor those of a highly specialised one. 


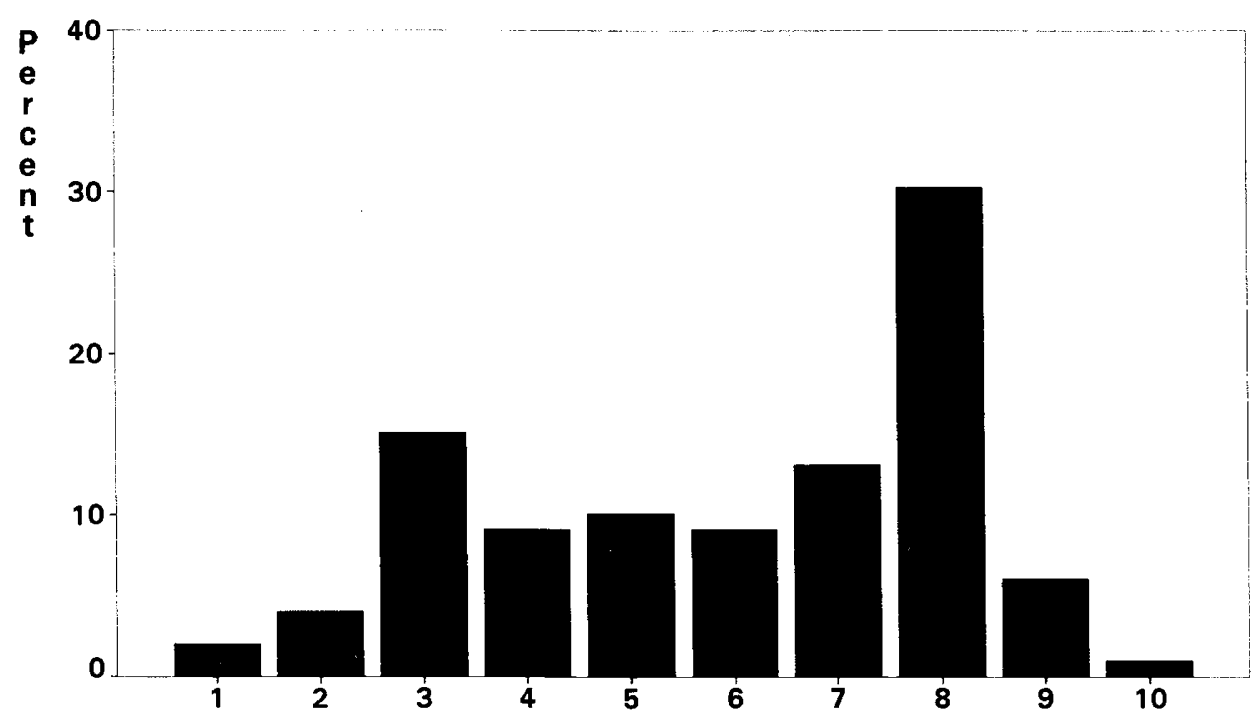

Number of products offered (today)

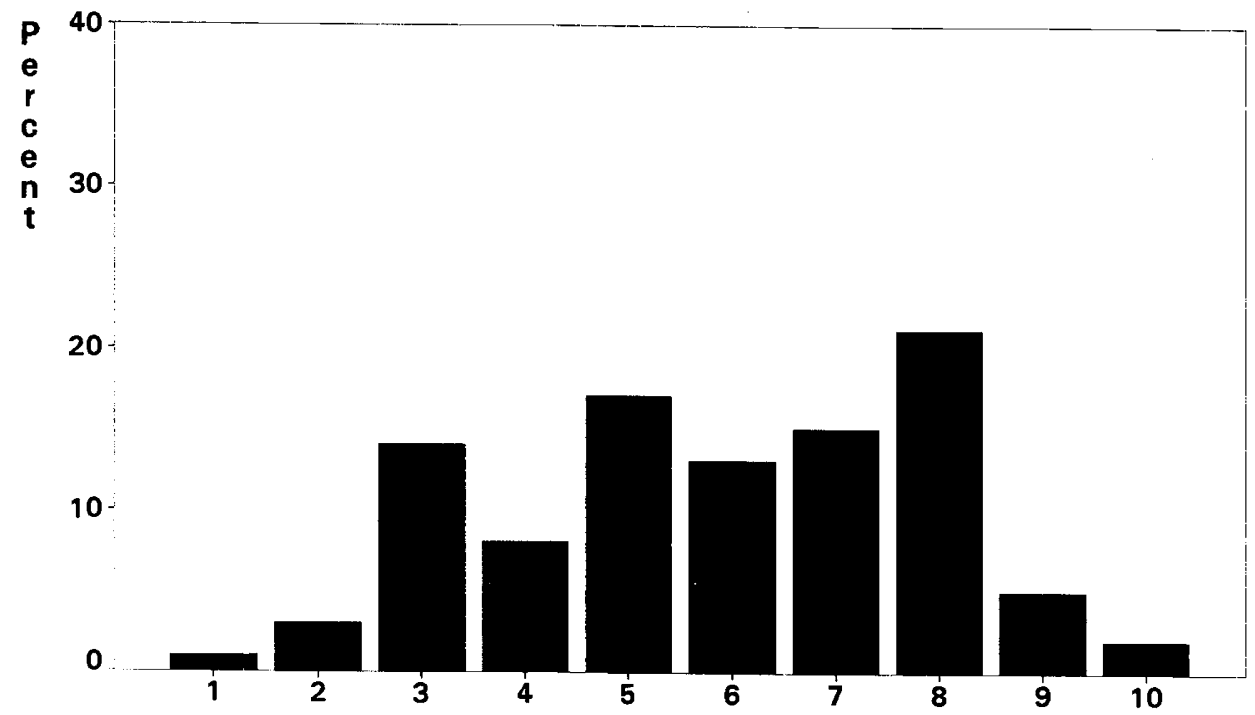

Number of products offered in 10 years time

The survey also investigated the possibility of polarisation in respect of the number of customer groups targeted with group-specific products. Here too there is no evidence for the assumption that in future insurers will either decide to specialise on a small number of 
customer groups or gear their product range to every possible customer group. Once again it is neither possible to detect a trend towards an all-encompassing approach nor towards a specialised one.

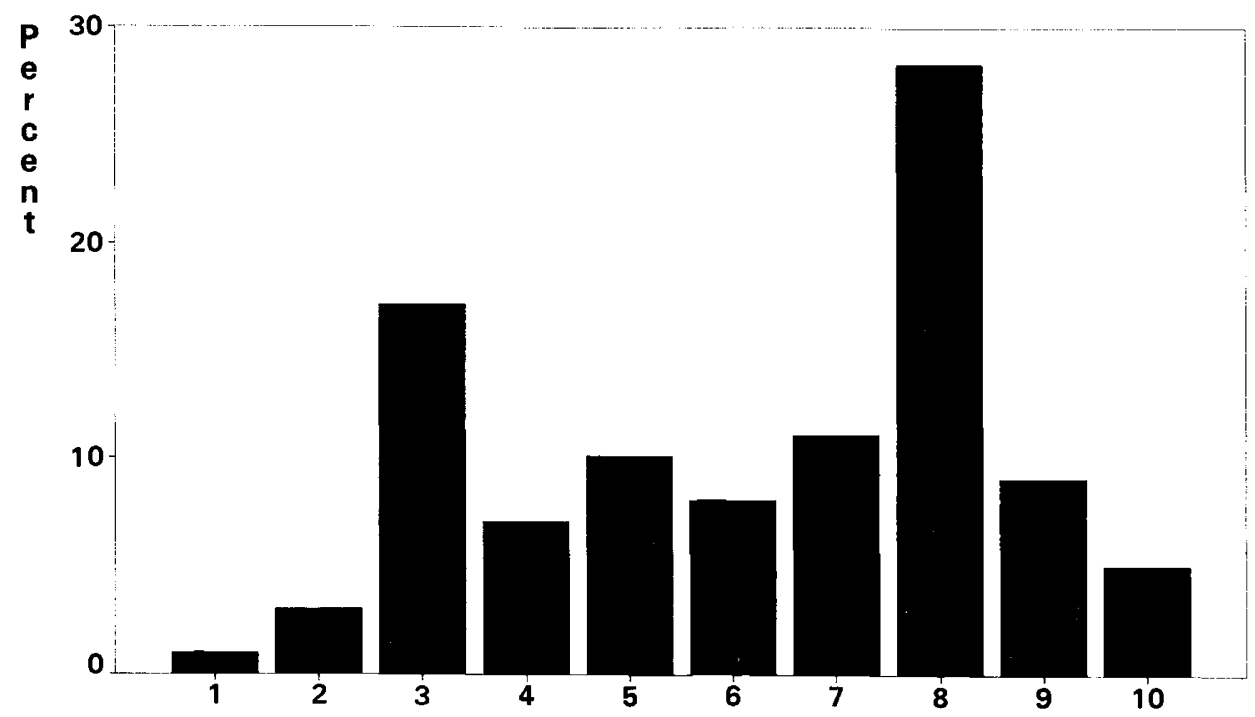

Number of targeted customer groups (today)
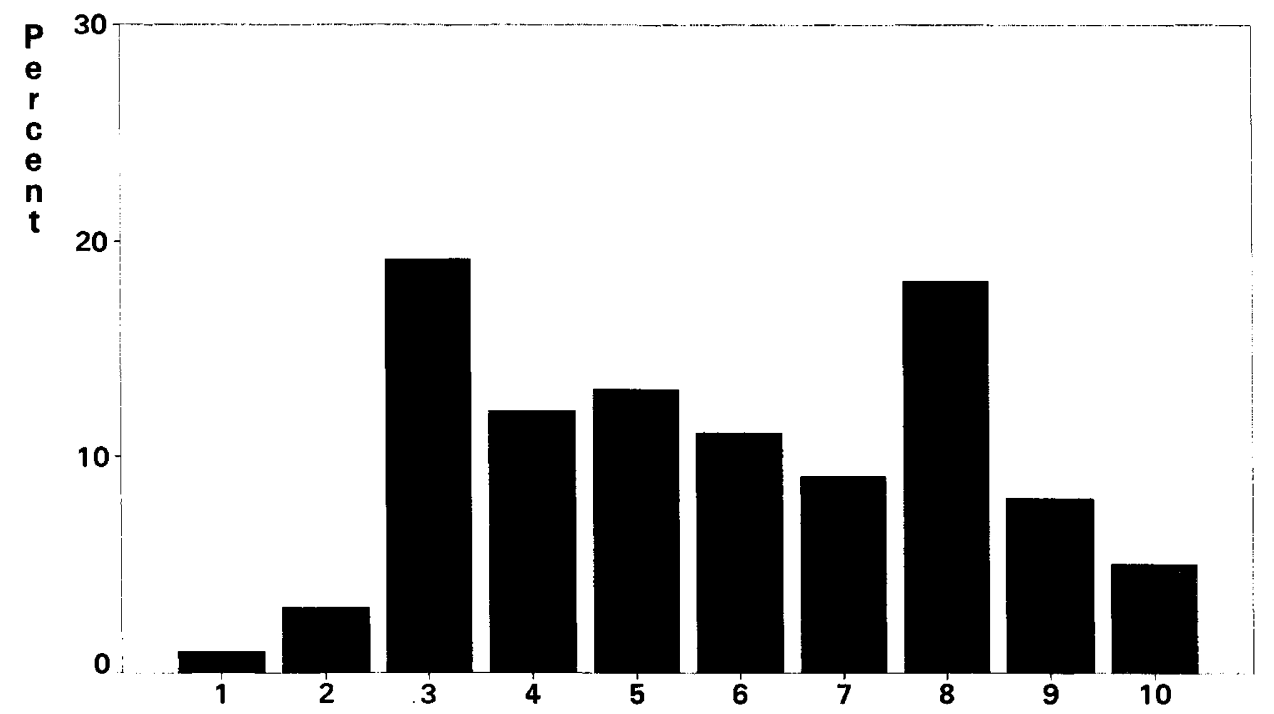

Number of targeted customer groups in 10 years time 


\subsubsection{Focus on product policy}

In relation to products the question was also asked whether in future insurers want to develop their own market profile or whether they prefer selling a product range whose qualities essentially correspond to the market average. The survey participants were first asked to show on a scale of 1 to 10 to what extent their products share the same characteristics as

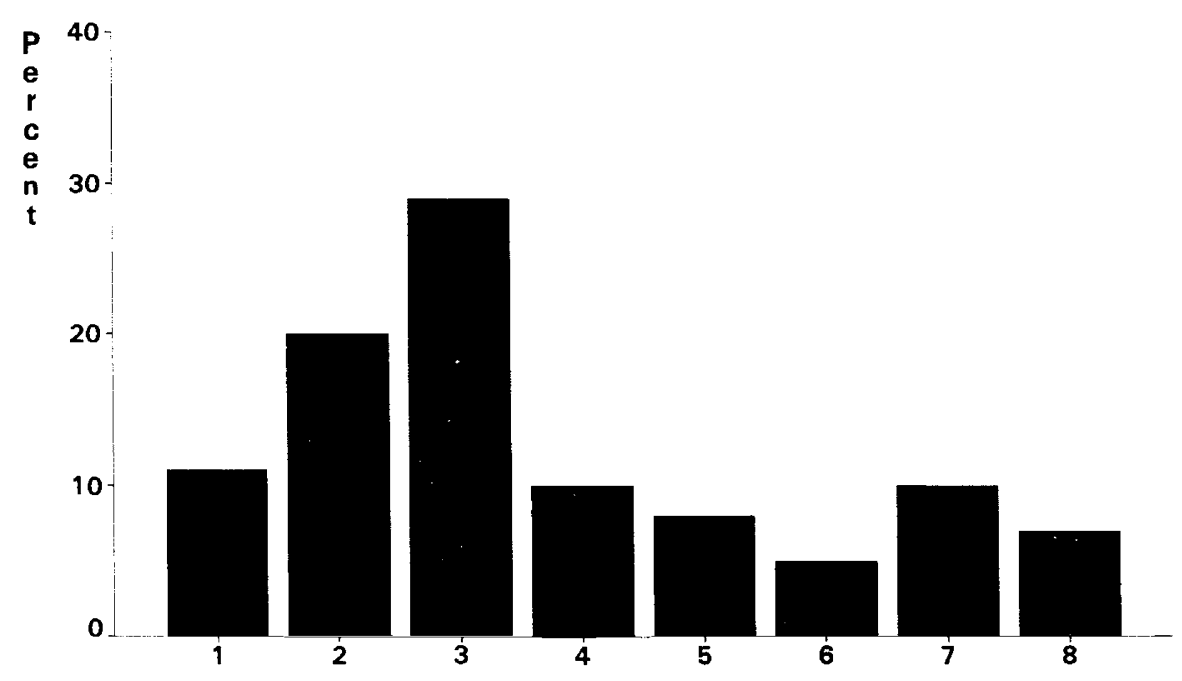

Product characteristics same/not same as others on the market (today)

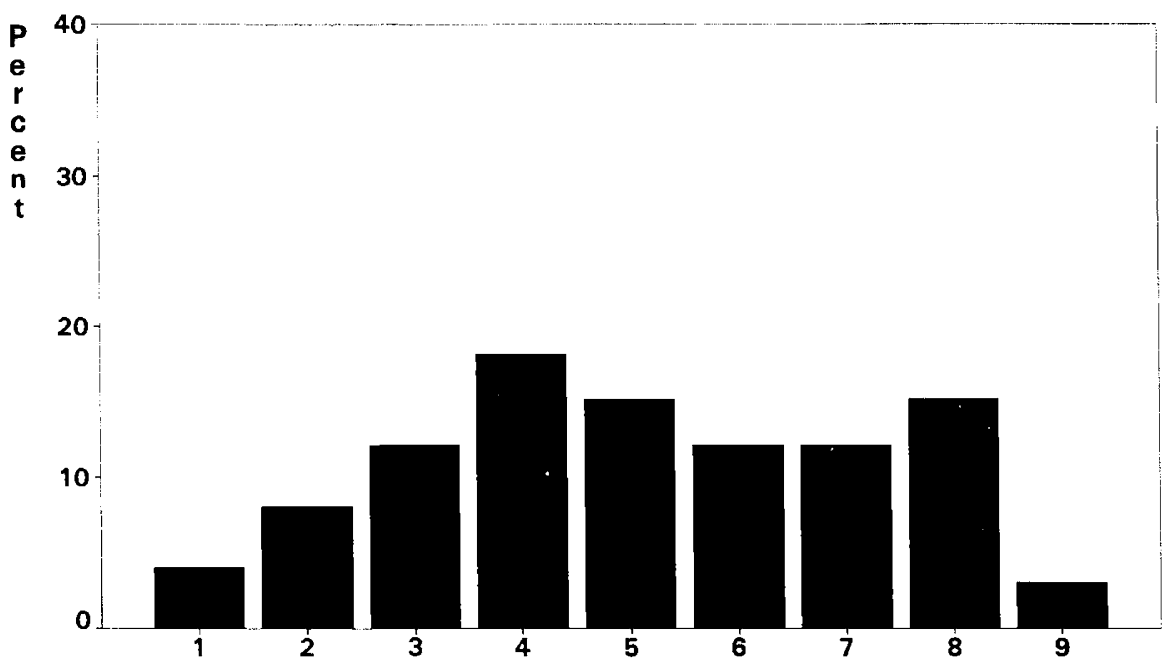

Product characteristics same/not same as others on the market (10 years) 
others on the market. Here low values represent characteristics generally the same as others in the market and high values represent characteristics seldom found elsewhere in the market. As can be seen in the diagram below, a definite trend away from the market average can be observed in the product characteristics of the surveyed undertakings. It seems that few prospects of success are held out for product policies that are solely orientated to the market average.

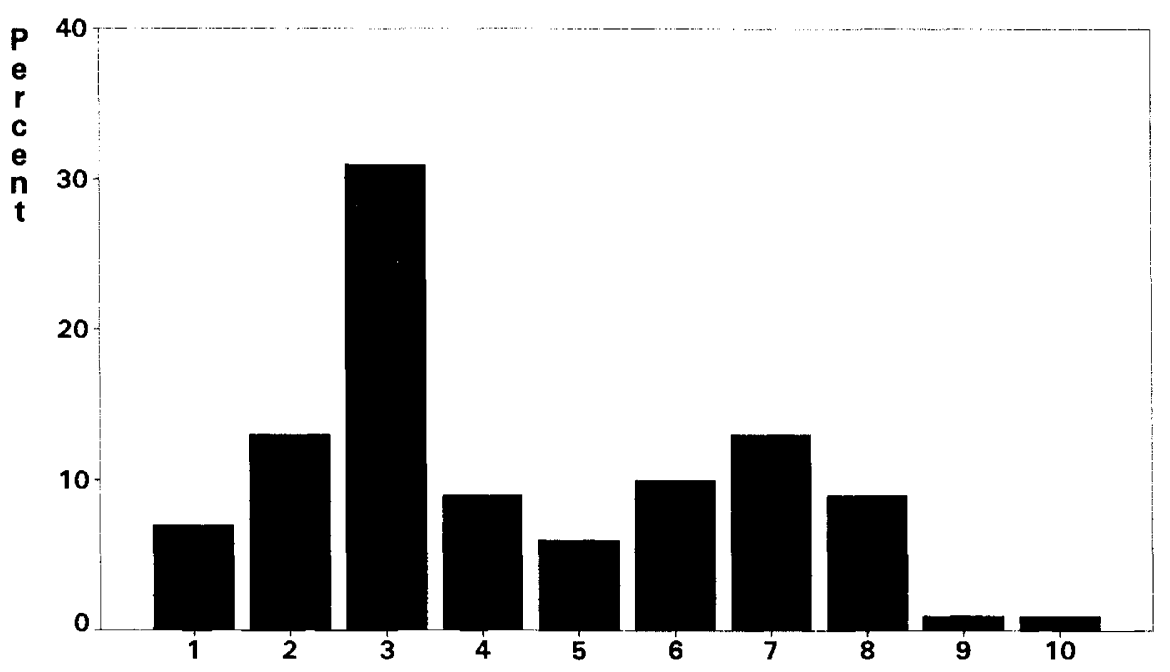

Standardised or tailor-made products (today)

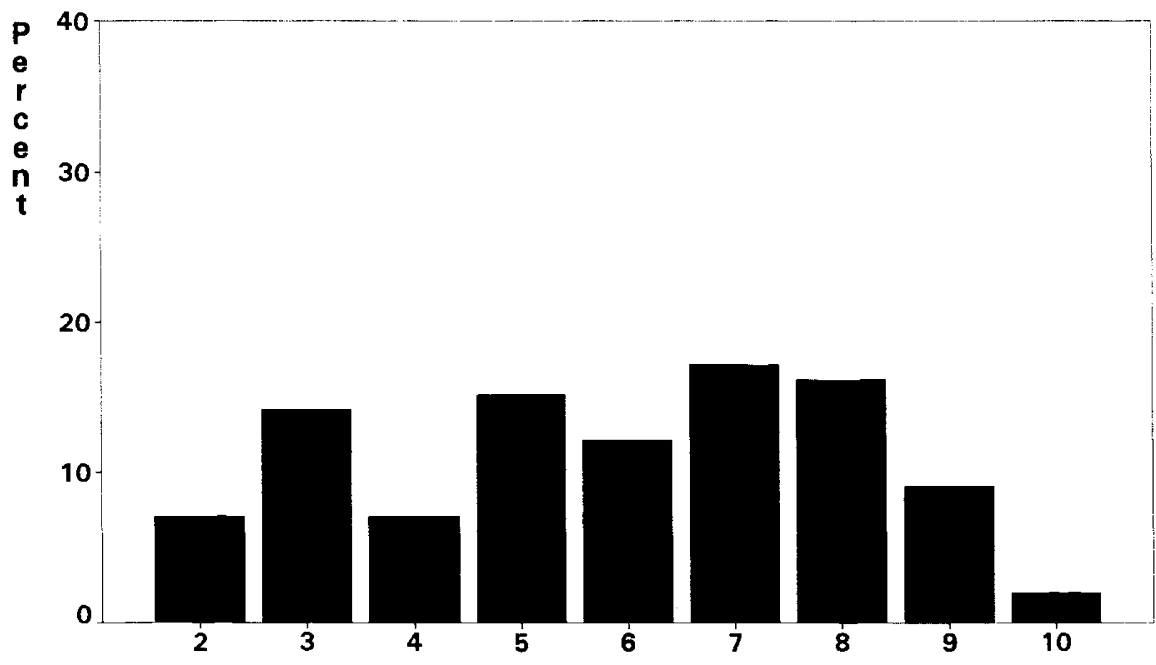

Standardised or tailor-made products (in $10 \mathrm{y}$. time); (no value for " $1 "$ ) 


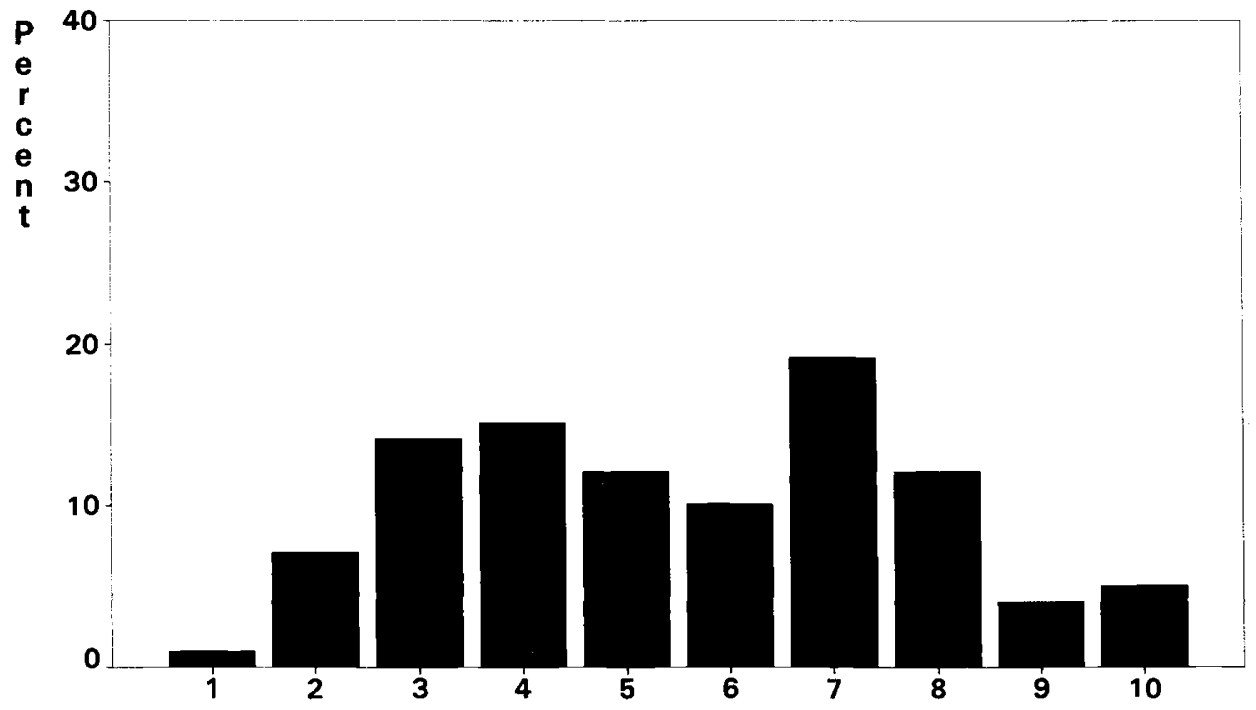

Product flexibility (today)

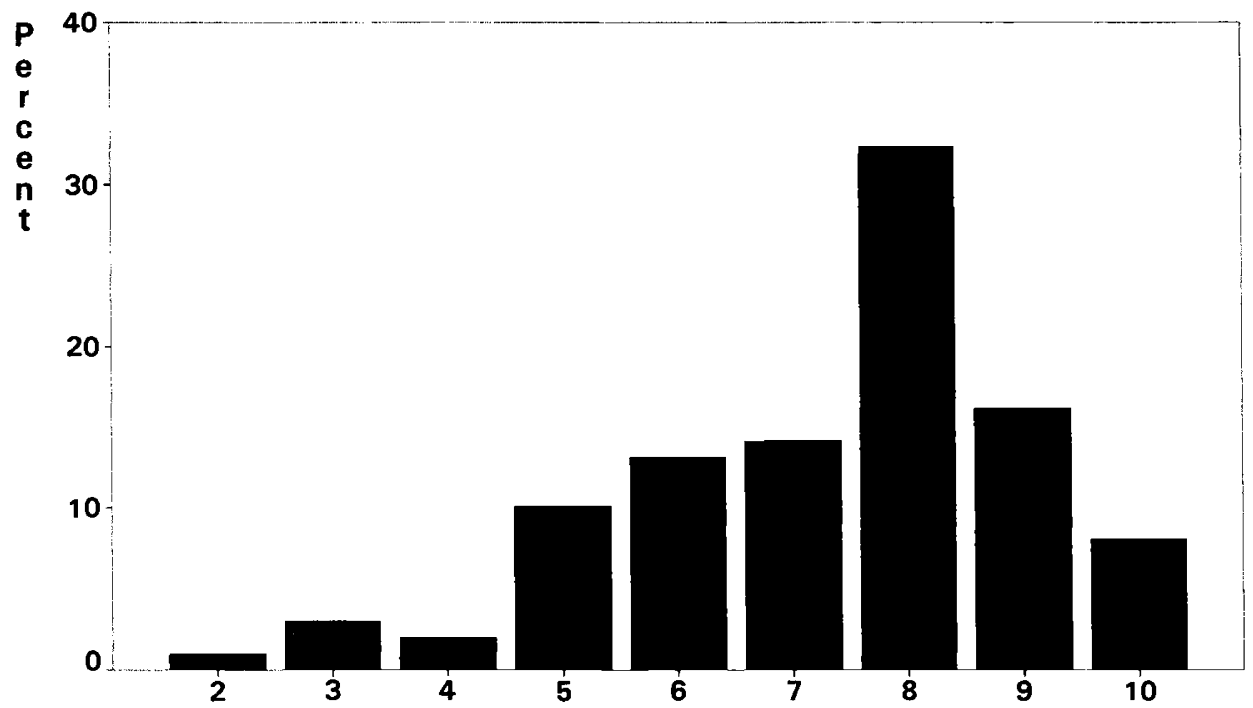

Product flexibility (in 10 years time); (no value for "1") 
It is apparent that there is a general intention to tailor products more closely to customers' individual requirements in the future. However, here again no tendency towards polarisation is apparent that would divide the market into companies selling standardised products (values 1-3) and those selling tailor-made products (8-10). In future, the majority of companies will in fact continue to offer products that are neither completely standardised nor completely tailor-made to meet customers' requirements.

Products may also be differentiated according to whether they can be easily adapted during a period of insurance to meet an insured's changed requirements (flexible products) or whether this is difficult or even impossible (inflexible products). As shown in the table below, a definite trend can be seen towards more flexible products, as indeed was the case with product differentiation. The low values attaching to positions 1-4 of the scale make it clear that insurers foresee virtually no market opportunities in future for inflexible products.

The recently observable trend to include additional services with insurance products (e.g. providing the insured with assistance services or risk management) will become more marked in future. A very high proportion of the survey participants include few or no additional services (1-3) with their current products; scarcely any insurer describes his products as including many (8) or very many (10) additional services. The prediction for ten years time is almost the mirror image of this; once again there are no signs of market polarisation, as the values for positions 1-3 are too low to indicate this and also because too many insurers consider themselves well placed for the future by remaining in the middle position (product range with neither too many not too few services).

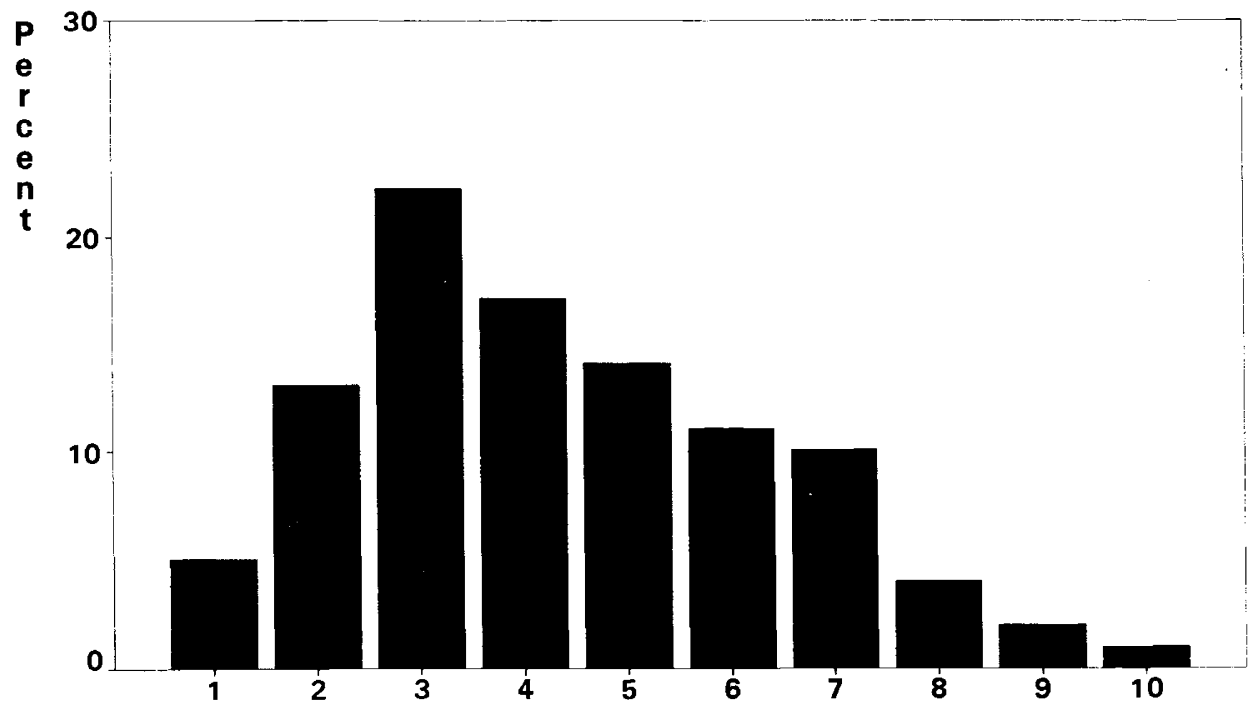

Number of additional services included with products (today) 


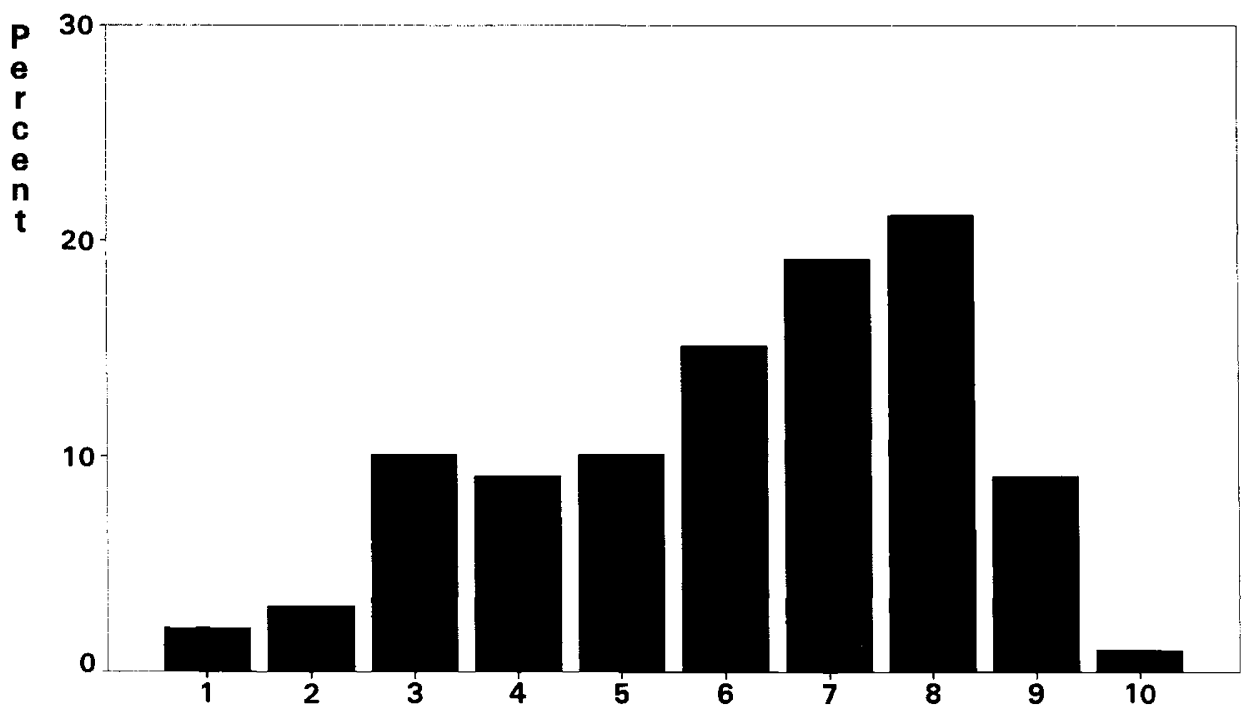

Number of additional services included with products (in 10 years time)

\subsubsection{Pricing policy}

An insurer's pricing policy is closely connected with his product policy. Flexible, tailormade products with many additional services give rise to higher costs and - in order to remain profitable - can therefore only be sold at higher prices than standardised, inflexible products with few additional services which entail comparatively low costs. Polarisation of insurers in connection with product policy should logically bring with it a polarisation of pricing policies that clearly separates the cheap insurers with simple product ranges from the "luxury insurers" selling high quality products.

The absence of recognisable polarisation in insurers' product policy is confirmed by the replies to the question concerning the future development of the survey participants' pricing policy. Of the undertakings asked, a majority of today's "low price insurers" also wishes to remain in that category in future. Some of those insurers whose prices are higher than the market average do not believe they will be able to maintain these prices in the future and therefore want to bring them into line with the market average. Thus the process of adjustment will increase the importance of the unfocussed middle position. 


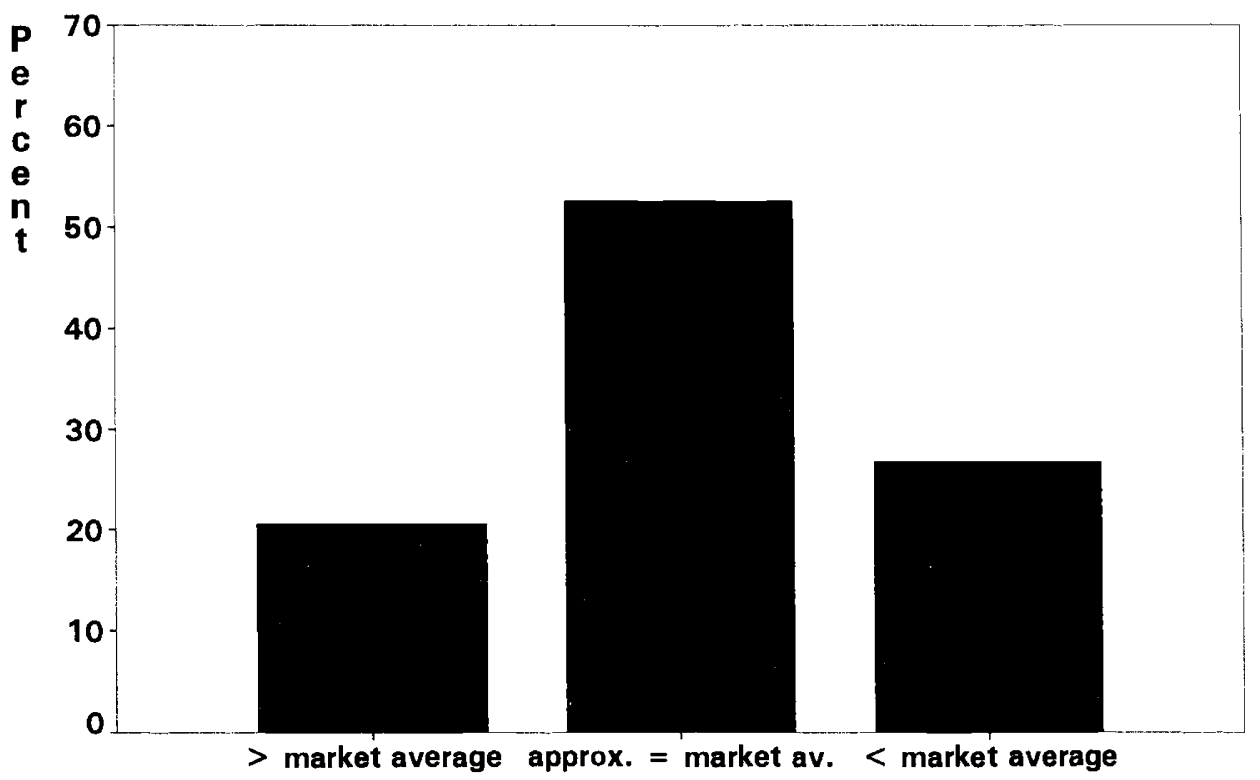

Pricing today

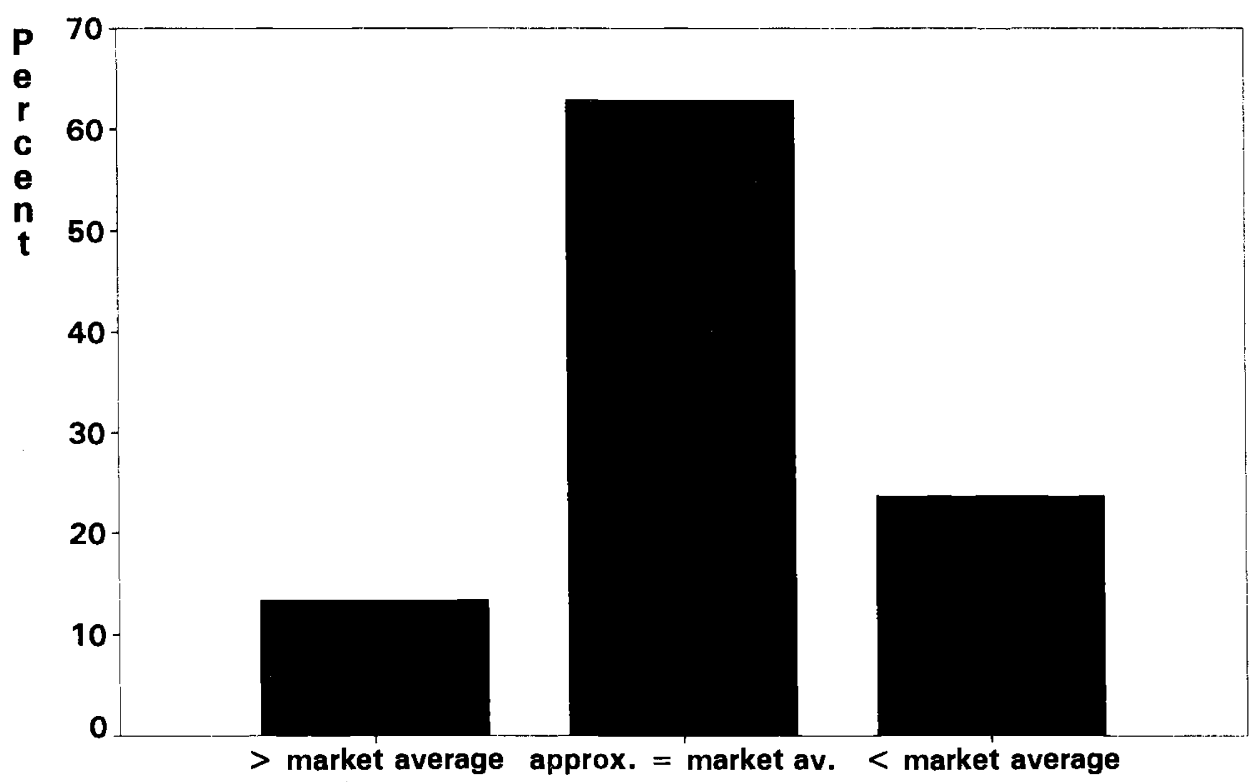

Pricing in 10 years time 


\subsubsection{Distribution policy}

Seen from the marketing point of view, the choice of distribution system is partially dependent on the complexity of the products and also on the extent to which they require explanation. Complex products that are tailor-made for an individual insured have to be explained to the customer before they can be sold and thus require the services of an insurance intermediary to provide the necessary advice. This is not necessarily the case where simple and standardised covers are concerned. The second factor influencing the choice of distribution system is the particular characteristics of the customer groups being targeted with the product. For example, customers who only have a limited understanding of insurance matters and therefore feel they need a high level of advice, will only buy even simple insurance products after a prior sales discussion with an intermediary. Customers with greater understanding and knowledge of insurance matters will find such advice superfluous (as well as the costs arising from it that have to be paid for via premiums) and may for example prefer to deal direct. An insurer with a wide product range who wants to meet these different requirements can only do so with a combination of different distribution systems. On the other hand, a specialist insurer can manage with fewer distribution systems.

No signs of a tendency towards polarisation could be detected in the selection of distribution systems. This is not surprising considering the absence of such tendencies in the surveyed insurers' product ranges. The few insurers currently only using one distribution system will predominantly continue to do so in future. None of the insurers currently using several distribution systems will give up a single one of them in future. There is thus no recognisable trend towards specialisation in particular distribution methods.

A general increase in the number of distribution methods used is much more likely. As a majority of insurers expects to transact less business in future via their own distribution networks and tied distributors, they must find suitable alternatives. $25 \%$ of the survey participants therefore expect to introduce direct selling as one of their distribution methods and $15 \%$ want to start selling their products over the bank counter within the next ten years.

\subsection{Strategies for international business policy}

The insurers were asked about their intentions to transact business in other EEA countries.

\subsubsection{Goals for direct insurance activities in other EEA states}

The insurers were first asked what goals they were pursuing in connection with direct insurance activities in other EEA states and how important these goals were to them. The answers are not very surprising. Growth targets come first, closely followed by profit targets. The third most important goal of foreign business activities was the ability to service international customers abroad. Following on at a somewhat lower level are the goals "gaining international know-how" and "prestige". The goal of "greater security by achieving an international spread of risk" was not perceived as being particularly important. It appears that risks in the European Economic Area are seen as so highly correlated that it is difficult to obtain a spread of risk thereby. 


\subsubsection{Attractiveness of direct insurance markets}

On the one hand, the attractiveness of direct insurance markets depends on the international goals being pursued and, on the other hand, on the significance for insurance business of each country's particular legal and economic environment. The survey participants were asked to evaluate overall "market attractiveness" on a scale of 1 (not attractive) to 10 (very attractive) on the basis of their individual assessment of target countries. The evaluation that some insurers made of their own country of origin (always a very positive one) was excluded for the purposes of the calculation. The table below shows the attractiveness of the various countries in order of importance:

\begin{tabular}{|l|c|}
\hline Country & Mean \\
\hline Germany & 6,73 \\
Italy & 6,27 \\
France & 6,14 \\
Spain & 6,08 \\
Great Britain & 5,38 \\
Switzerland & 5,33 \\
Austria & 5,21 \\
Netherlands & 5,13 \\
Portugal & 4,94 \\
Belgium & 4,26 \\
Eire & 4,21 \\
Sweden & 4,16 \\
Luxembourg & 4,12 \\
Greece & 4,11 \\
Denmark & 3,67 \\
Turkey & 3,46 \\
Norway & 2,97 \\
Finland & 2,41 \\
\hline
\end{tabular}

The table shows that markets with a large volume of business are fundamentally more attractive than small markets. The latter are only of interest for international expansion if they offer considerable possibilities for growth.

The main reasons for evaluating Germany as the most attractive market must be its business volume and its profitable turnover. In view of the poor prospects for growth in Germany, it is unlikely to make a really significant contribution to growth targets. Fears that profits will be substantially reduced by the effects of deregulation do not appear to be shared by foreign competitors. 
The high ratings given to Italy and Spain can be principally explained by anticipated growth. In addition, Italy may have been selected for better profit prospects as price increases are expected there due to the lifting of the requirement for state approval of premiums, that were kept artificially low, for example, in motor liability insurance. ${ }^{11}$

It is hard to explain the high rating accorded to France in terms of anticipated profits and growth. As France has a large and already well developed insurance market, its growth potential is limited and profitable turnover has also been low in the past. Perhaps new developments are hoped for arising from the extensive privatisation programme for the stateowned sector within the insurance industry.

Following on behind at a somewhat lower level from the peak group are the well developed insurance markets of Great Britain, Switzerland, Austria and the Netherlands. Great Britain has the largest volume of business, although Switzerland and Austria are perceived as the more profitable markets. The fact that Switzerland is not a member of the EU does not appear to damage its attractiveness. This can be explained by the very close ties based on its insurance agreement with the EU.

Turkey and Norway are seen as the least attractive of the non-EU markets; whilst the new EU member Finland is at the bottom of the table. These are all small insurance markets whose future prospects are hard to predict for political and/or economic reasons.

\subsubsection{Strategies for market entry}

\subsubsection{Introductory remarks}

The fact that foreign insurance markets are considered attractive does not in itself reveal whether attempts to enter these countries' markets are actually being planned.

The question about what new direct insurance activities are being planned for other EEA markets was asked to determine whether the already considerable international connections within European markets will continue to increase in future or whether insurers have by now completed the geographic expansion of their business activities. There was a very muted response to this question. International expansion plans are very sensitive company information which undertakings are unwilling to disclose, despite assurances of complete anonymity.

$68 \%$ of the survey participants who had authority to decide whether to engage in business activities abroad indicated that they are not currently planning any new direct insurance activities in the EEA. This agrees with the often voiced expectation that even after the completion of the internal insurance market, most European insurers will continue to restrict their operations to a national level. Only $70 \%$ of the remaining insurers were prepared to provide more information about their plans for international expansion. Thus the only information available concerns 40 international expansion plans made by 16 insurers. This sample is too small for any general conclusions to be drawn from it; however, certain particular indications may be inferred from the answers.

${ }^{11}$ See Nebel, Rolf: Die Rahmenbedingungen der Motorfahrzeug-Versicherung im europäischen Binnenmarkt [The Conditions for Motor Insurance in the European Internal Market], in: Schweizerische Versicherungs-Zeitschrift, 62nd year, p. 140. 
With the exception of one Portuguese insurer, new direct insurance activities were being pursued exclusively by insurers from the major insurance markets. The aggressive stance expected of the French, German and British insurers is confirmed by the comparatively large number of new international expansion plans declared by undertakings from these markets. No such information was provided by the Swiss insurers, who are also perceived as being very interested in international expansion.

\subsubsection{Choice of target markets}

The information in respect of target markets agrees with the evaluation of the attractiveness of the direct insurance markets. Germany, Italy, France, Spain and Great Britain are named as the targets for planned foreign business activities.

\subsubsection{Market operating strategies}

\subsection{Organisational methods used for commencing foreign business activities}

The following organisational methods may be used to operate abroad:12

- no local presence (making use of freedom of services)

- setting up a new branch

- creating a new subsidiary

-- buying a local insurance undertaking

- cooperation with a local insurance undertaking, possibly involving a minority shareholding.

The organisational methods most favoured by European insurers for commencing direct insurance activities in other EEA states is through freedom of services. This is in contradiction to the opinion that customers are relatively unwilling to purchase cover from an insurer without a local presence. An explanation for this could be that the use of freedom of services is almost always only named as the favoured market entry strategy when a neighbouring country's market is being targeted. For example, intermediaries located close to the border can easily extend their field of operations into the neighbouring country by means of so-called "small-scale cross-frontier traffic". This provides the local presence that - despite freedom of services - is so important, at least in so far as personal lines insurance business is concerned. This marketing approach greatly increases the prospects of success. A further explanation is that freedom of services incurs the lowest expansion costs, thus considerably limiting the risks of operating abroad. An undertaking can also use freedom of services as an easy way of testing the marketability of its products, so that the prospects of a planned branch or subsidiary may be assessed in advance.

After freedom of services, the purchase of a local insurance undertaking is specified as the second most favoured market entry strategy. This option is above all used to enter highly developed markets with limited growth prospects, as it allows the buyer to acquire market share quickly, which would otherwise take decades if starting up with a new branch or subsidiary. However, the large number of company acquisitions in the past has resulted in suitable takeover candidates becoming a rarity in many markets, and thus expensive.

${ }^{12}$ See Attiger, Peter: Internationale Wettbewerbsfähigkeit in der Versicherungsbranche [International Competitiveness in the Insurance Industry], Karlsruhe 1994, pp. 37-41. 
The creation of a new subsidiary is the favoured strategy for entry into the Spanish market, whose growth prospects clearly make it appear possible to build up a reasonable portfolio of business within a foreseeable period of time. Otherwise, the targets of foreign expansion plans consist almost exclusively of highly developed insurance markets with weak growth prospects and it is therefore not surprising that strategies involving new branches or subsidiaries are seldom chosen.

Methods involving cooperation are not considered suitable for entering foreign insurance markets, as their effectiveness is frequently impaired by conflicts of interest between the cooperating undertakings.

\subsection{Products}

The majority of answers specified the intention of selling life assurance in the foreign markets, followed by non-life products. Health insurance, which is most developed by far in Germany and the Netherlands, is hardly perceived by insurers as an "export item". Twothirds of all plans for international expansion express a preference for selling standardised products rather than tailor-made ones. Only a few insurers offer both types and want to widen their product range.

\subsection{Customer groups}

Nearly all expansion plans target the generally more profitable personal lines and small commercial risks sectors, where customers are fairly similar to each other in terms of their requirements and consumer behaviour. Only in quite exceptional circumstances is there any intention of acquiring major commercial customers. This would appear to contradict the preference expressed for freedom of services as the method of undertaking business activities abroad, in particular, in view of the perceived unwillingness of private insureds to purchase cover from an insurer without a local presence. This supports the conjecture made in 5.3.3.3.1. that freedom of services is only a first step towards international expansion, taken in order to evaluate business prospects in a foreign market. A local presence can then be established if the chances of success appear reasonable.

\subsection{Distribution methods}

Half the survey participants want to employ a number of distribution systems in foreign markets, the other half intends to use only a single distribution method. Local brokers or the multi-company agencies are the most favoured distribution channel. The advantage of this method is that as a rule broker networks with complete geographic coverage already exist. A foreign insurer can make use of these networks much more quickly than an in-house sales force, which takes a great deal of time and expense to build up. On the other hand distribution via brokers is not unproblematic for insurers either, as these intermediaries' core activity is the provision of tailor-made insurance solutions for large commercial customers. Personal lines business tends to be more of a sideline, although it is precisely this customer group primarily being targeted abroad. Secondly there is a danger of negative risk selection by brokers, who may prefer to pass the good risks on to the domestic insurers with whom they have long-standing business relationships and offer the bad risks to the foreign companies' underwriters. Many insurers obviously perceive the creation of an in-house sales force as being so expensive and time-consuming that distribution via brokers still appears to offer better prospects of success, despite the disadvantages. 


\subsubsection{5. "Demarcation" or "adaptation" strategies}

Two basic marketing strategies are possible in a foreign market: either "adaptation" to the marketing methods of the target market or application of the marketing strategies used in the home market ("demarcation strategy"). ${ }^{13}$ Adaptation and demarcation strategies are equally popular with the survey participants when considering international expansion projects as a whole. Taking account of the limited data available, it is possible - with all due caution - to identify the preferred strategies for three markets. Out of five expansion projects in France, four undertakings opted for the adaptation strategy and only one preferred the demarcation strategy. On the other hand, all five plans for international expansion in Italy and all four plans for Austria are based on demarcation strategies.

In over $80 \%$ of all cases, insurers intend to make use of product competition based on new insurance products as their primary marketing tactic. Aggressive price competition initiated by new foreign undertakings is therefore an unlikely prospect. Here it is interesting to note that the distribution of answers hardly varies according to target market. This means that, even in previously highly regulated markets with comparatively high price levels, an appropriate product policy is deemed to have better prospects than a policy based on pricing.

\section{Conclusion}

Despite the EC Insurance Directives' far-reaching harmonisation of legal environments, a unified European internal insurance market will probably not develop for a long time to come. The national markets with their individual characteristics will probably continue to exist for some time despite the ease with which they can be entered by foreign undertakings. The survey results indicate that the improved economic climate and the absence of any spectacularly negative events in the first months of the European internal insurance market have calmed the situation somewhat. The far-reaching changes of market structure feared by some have not occurred yet and the predicted polarisation on the supply side has so far hardly been noticeable. This does not mean that both these developments will not take place, but it does show that these processes will take a long time. The slow pace of these changes will allow undertakings to adjust their business policy gradually to the new environment. This is also to be welcomed as far as the consumers are concerned. If they wish to protect themselves against unpleasant surprises in the freely accessible deregulated insurance markets they will need to develop skills that cannot be acquired overnight.

${ }^{13}$ See Farny, Dieter: Erwartungen europäischer Versicherer an den Binnenmarkt [European Insurers' Expectations for the Internal Market], as above, p. 83. 


\section{REFERENCES}

ANDERSEN CONSULTING (Ed.): Insurance in a Changing Europe, Special Report No. 2068, London 1990.

ANDERSEN CONSULTING (Publisher): Zur Entwicklung des europäischen Versicherungsmarktes [The Development of the European Insurance Market] 1990-1995, Stuttgart 1991.

ATTIGER, Peter: Internationale Wettbewerbsfähigkeit in der Versicherungsbranche [International Competitiveness in the Insurance Industry], Karlsruhe 1994, pp. 37-41.

FARNY, Dieter: Über mögliche Unternehmensstrategien deutscher Erstversicherer im deregulierten Versicherungsmarkt [Possible Business Strategies of German Direct Insurers in the Deregulated Insurance Market], in: Risiko. Versicherung. Markt, Festschrift for Walter Karten, Karlsruhe 1994, p. 248 et seq.

FARNY, Dieter: Ein Konkurssicherungsfonds in der Versicherungswirtschaft, Ei des Kolumbus oder Windei? [A Protection Fund for the Insurance Industry, Solution or Illusion?], Karlsruhe 1990

FARNY, Dieter: Erwartungen europäischer Versicherer an den Binnenmarkt [European Insurers' Expectations for the Internal Market], in: ZVers. Wiss., Vol. 78, 1989, pp. 67-106.

FINSINGER, Jörg, Schmid, Frank A.: Gebundener versus ungebundener Vertrieb. Theorie und empirische Evidenz für europäische Versicherungsmärkte [Tied versus Independent Distributors. Theory and Empirical Evidence for European Insurance Markets], in: Zeitschrift für Betriebswirtschaftliche Forschung, 45th year, 1993, pp. 216-226.

FINSINGER, Jörg: An Integrated Market in Western Europe - Selected Issues, in : Emil Ems (Editor): Financial Integration in Western Europe - Structural and Regulatory Consequences, Sveriges Riksbank, Occasional Paper 10, (place and date not stated), p. 87.

FINSINGER, Jörg: Konkurssicherungsfonds und optimale Sicherheitsregulierung [Protection Funds and Optimum Security Regulations], in: Geld Banken und Versicherungen [Money, Banks and Insurance], Karlsruhe 1987, Volume 2, pp. 1213-1254.

LOHEAC, Francis: Der Binnenmarkt für Versicherungen: Chancen, Grenzen und Perspektiven [The Internal Insurance Market: Opportunities, Limits and Perspectives], in: Versicherungswirtschaft, 49th year, 1994, pp. 1116-1127.

MUTH, Michael: Versicherungswirtschaft im Umbruch [The Insurance Industry in a Time of Change], in: Versicherungswirtschaft, 49th year, 1994, p. 291 et seq.

NEBEL, Rolf: Die Rahmenbedingungen der Motorfahrzeug-Versicherung im europäischen Binnenmarkt [The Conditions for Motor Insurance in the European Internal Market], in: Schweizerische Versicherungs-Zeitschrift, 62nd year, pp. 137-150. 